\title{
The harbor of microorganism on used toothbrushes Kandungan organisme mikro pada sikat gigi yang telah digunakan
}

\author{
Asmawati \\ Department of Oral Biology, \\ Faculty of Dentistry, Hasanuddin University \\ Makassar, Indonesia
}

\begin{abstract}
ABSTRAK
Tujuan penelitian ini adalah untuk mengetahui organisme mikro yang terdapat pada sikat gigi yang telah digunakan. Sampel pada penelitian ini adalah 25 sikat gigi; 10 sikat gigi yang digunakan kurang dari 3 bulan, 10 sikat gigi yang telah digunakan selama 3-6 bulan, dan 5 sikat gigi yang telah digunakan lebih dari 6 bulan. Telah ditemukan beberapa kokus gram positif, diantaranya Staphylococcus, Streptococcus dan Diplococcus. Hasil penelitian ini menunjukkan bahwa ada beberapa jenis organisme mikro yang ditemukan pada sikat gigi yang telah digunakan. Sikat gigi yang telah digunakan lebih dari 6 bulan, lebih banyak terkontaminasi organisme mikro daripada sikat gigi yang digunakan kurang dari 3 bulan dan 3-6 bulan. Disimpulkan bahwa makin lama sikat gigi digunakan, makin banyak jumlah organisme mikro ditemukan pada sikat gigi.
\end{abstract}

Kata kunci: sikat gigi, kontaminasi organisme mikro

\begin{abstract}
The purpose of this study was to evaluate the microorganisms found on used toothbrushes. In this study 25 toothbrushes were investigated, 10 toothbrushes were used less than 3 months, 10 toothbrushes have been used for 3-6 months, and 5 toothbrushes have been used for more than 6 months. Some gram-positive coccus, such as Staphylococcus, Streptococcus and Diplococcus. The results showed there were microbial harbored of used toothbrushes. Toothbrushes that have been used for 6 months were harbored more microorganisms than the toothbrushes that have been used less than 3 months and 3-6 months. It can be concluded that the longer using time of toothbrush the more increase of microorganism amount found on toothbrush.
\end{abstract}

Key words: toothbrush, microorganism contamination

Correspondence: Asmawati, Department of Oral Biology, Faculty of Dentistry, Hasanuddin University, Jl. Perintis Kemerdekaan Km.10, Makassar, Indonesia. E-mail: asmaamin68@yahoo.com

\section{INTRODUCTION}

Oral health of Indonesian people is still a major concern. The objective of oral health is to gain a healthy mouth and good dentition, and also a good function of speech and mastication. ${ }^{1}$ Oral health status is influenced by four important factors; namely heredity, environment (physical and social culture), behavior, and health service. Of those four factors, behavior plays an important role in oral health status and could influence environment and health service factors. ${ }^{2}$

Theoritically, once-a-day teeth cleansing is enough to prevent plaque attachment. However, it is already settled to brush the teeth twice a day to gain a healthy mouth. Therefore it needs to build a good understanding in increasing the awareness of good oral health. The frequency of teeth cleansing is one of the behavioral forms that will affect oral health condition, influence caries risk, and periodontal disease. ${ }^{1}$

Toothbrushing and other mechanical steps are the simplest and the most effective behavior to maintain good oral health, which is still the most efficient way to have a good oral health. ${ }^{3}$

Retention and longlife of microorganisms on toothbrush could cause recontamination from mouth. Toothbrush used regularly is contaminated by microorganisms that invade oral cavity, and the longer its use, the higher amount of microorganisms could be harbored on toothbrush. Research in Manchester University showed that more than 100 million bacteria could be found in one toothbrush, such as E.coli, Staphylococci, Streptococcus and Candida. ${ }^{4}$

When keep more than one toothbrush, they need to be separated so the microorganisms will not contaminate one another. Microorganism found in the environment could also exist on the toothbrushes. Toothbrush may be contaminated by bacteria from a toothbrush box, because it is not always in sterile, but human body is continuously in a risk to be invaded by microba and the body has a system to protect against the microba and avoid the infection. ${ }^{5}$ 
There is no clinical fact of the toothbrush on the harbor of microorganisms on used toothbrushes. Toothbrush should be replaced when the condition of bristles is already wave out, which is an indicator of replacing one toothbrush. The way of brushing tooth and keeping the toothbrush may influence the using time of toothbrush. ${ }^{6}$

Toothbrush is used in daily life by everyone in the world, therefore it needs to be cleaned to avoid the microorganisms that could cause various diseases. ${ }^{4,7}$ The objective of this study is to evaluate microorganisms on used toothbrushes.

\section{MATERIALS AND METHODS}

The is an experimental study using 25 toothbrushes as samples, which 10 toothbrushes have been used less than 3 months, 10 have been used between 3-6 months, and the other 5 have been used more than 6 months.

The samples of this study were used toothbrushes, chocolate bottle, small needle, ose/spread glass, incubator, gloves, mask and microscope to observe bacteria, saline, and BHIA. The test was conducted with the plantation on
BHIA medium. The grown bacteria, is taken to the gram coloring test.

\section{RESULTS}

This study is conducted in Microbiology Laboratorium, Faculty of Dentistry, Hasanuddin University. Microorganisms found on the plantation with BHIA medium test and coloring test, are in coccus form (Fig.1).

Table 1 showed the toothbrushes that have been used for more than 6 months had more microorganisms 579.4 (40.97\%) compared to the toothbrushes that have been used for less than 3 months and between 3-6 months.

Table 2 showed of 25 used toothbrushes, Staphylococcus could be isolated from those 25 toothbrushes, followed by Streptococcus found on 22 toothbrushes and the least bacteria isolated is Diplococcus found on 8 toothbrushes.

\section{DISCUSSION}

Those three microorganisms identified on the samples, of used toothbrushes, are coccus gram positive bacteria. They are Streptococcus, Staphylococcus, and Diplococcus, which is able to grow on the prepared medium, BHIA.

Table 1. The average number of colonies by the duration of the used of toothbrush

\begin{tabular}{cccc}
\hline Duration & Average Number Of Colonies & $\mathbf{( \% )}$ & Colonies \\
\hline$<3$ month & 147.6 & $20.87 \%$ & Staphylococcus, Streptococcus and Diplococcus \\
$3-6$ month & 269.8 & $38.16 \%$ & Staphylococcus, Streptococcus and Diplococcus \\
$>6$ month & 579.4 & $40.97 \%$ & Staphylococcus, Streptococcus and Diplococcus \\
\hline
\end{tabular}

Table 2. Type of coccus gram positive microorganisms which can be identified from the 25 used toothbrushes.

\begin{tabular}{cccc}
\hline \multirow{2}{*}{ Toothbrush } & \multicolumn{3}{c}{ Microorganism genus } \\
\cline { 2 - 4 } & Staphylococcus & Streptococcus & Diplococcus \\
\hline 25 & $\mathrm{~V}$ & $\mathrm{~V}$ & \\
22 & & & $\mathrm{~V}$ \\
8 & & & \\
\hline
\end{tabular}

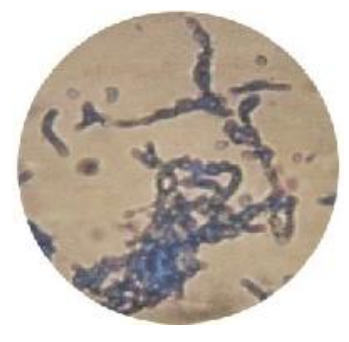

Streptococcus

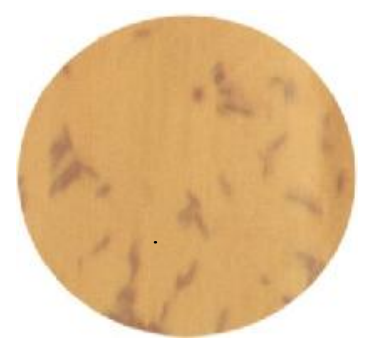

Staphylococcus

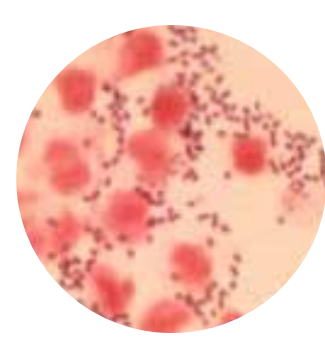

Diplococcus

Fig. 1. Bacteria type (Source: www.infogigi.com/info-gigi/) 
The used toothbrush could cause reinfection of an individu. The toothbrush used regularly will be contaminated by microorganisms that invade the oral cavity, thus the longer time of used toothbrush, the more of microorganism on it. ${ }^{8}$

The increased amount of microorganisms may be caused by improper storage, such as keep the toothbrush in humid bathroom, that will cause microorganisms growth more rapidly. ${ }^{5}$

In addition, toothbrush box that also influence the microorganism growth such as stored without hanging, causes the water is still maintained on the toothbrush that will increase the amount of microorganisms. Wet environment will make easier for microorganism to stick and remain there for long time. ${ }^{5}$

In this study, Staphylococcus found on the toothbrush is the normal flora of human skin. This is relevance with the fact that most people use finger to clean their toothbrush. Streptococcus is the most dominant microorganism found in mouth or on the toothbrush right after brushing. But after a while, a small amount readily of Streptococcus is also found, which is caused by their inability to remain on the toothbrush.

Streptococcus is found on all toothbrushes, but after being dried out for 24 hours, Streptococcus is only found on a few toothbrushes. Diplococcus is also found on toothbrushes with a bad storage system causing the toothbrush is contaminated with air. ${ }^{9}$

In this study, it was found that the amount of bacteria increased on toothbrush was related to the using time of toothbrush, therefore it is suggested to replace the toothbrush after 3 months used. ${ }^{10}$

\section{CONCLUSION}

The longer using time of toothbrush the more microorganisms will be found on toothbrush. The toothbrush that has been used for 6 months has more microorganisms compared to toothbrush that has been used less than 3 months and between 3-6 months.

\section{SUGGESTION}

From the result of this research, it is suggested to do further research to identify another microorganism in toothbrush by using another media, not just limited to coccus gram positive bacteria, and it is important to control other variables such as toothbrush brand and restorage system. So, it is important to replace toothbrush every 3 months.

\section{ACKNOWLEDGEMENT}

The author appreciate very much to Afrianti and Dian Permana for their support to complete this study in collecting data at Laboratory of Oral Biology Faculty of Dentistry Hasanuddin University.

\section{REFERENCES}

1. Stoll FA. Dental health education. 5th Ed. Philadelphia: Lea \& Febiger; 2000. p. 31-5.

2. McGuire. Tooth fitness your guide to heallthy teeth. Nevada: St. Michaels Press; 2001. p. 126-8.

3. Das UM, Singhal P. Tooth brushing skills for the children aged 3-11 years. J Indian Soc Pedod Prev Dent 2009; 27: 104-7.

4. Wetzel WE, Schaumburg C. Microbial contamination of toothbrush with different principles of filament anchoring. J Am Dent Assoc 2005; 136 (6): 758-65.

5. Szhicgoleit A, Kroeger T. Toothbrush care, cleaning and replacement. J Am Dent Assoc 2006; 137-8.

6. Hagan PP, Sherill CA. Home oral hygiene for the child and adolescent. In: Donna SS, editor. Dentistry for the child and adolescent. 5th Ed. St. Louis Mosby Inc.; 2002. p. 264-7.

7. Finegold SM, Rosenblatt JE. Oral anaerobic infections. In: Baird AT, editor. Scope monograph on anaerobic infectios. 3rd Ed. The Upjohn Co.; 2003. p. 118-25.

8. McDonald RE, Avery DR. Natural protective mechanism of the mouth.: Donna SS, editor. Dentistry for the child and adolescent. 5th Ed. St. Louis Mosby Inc,; 2002. p. 254-9.

9. Munksgaard. Prevention of bacteria induced inflamatory periodontal diseases. In: Goran K, Sven P, editor. Pediatric dentistry. 5th Ed. Copenhagen; 2001. p. 247-8.

10. Bastian RJ. The cleaning efficiency of different toothbrushes in children. J Clin Periodontol 2003; 13: $837-40$. 